\title{
molecules
}

ISSN 1420-3049

http://www.mdpi.org

\section{Regioselectivity in the Thermal Rearrangement of Unsymmetrical 4-Methyl-4H-1,2,4-triazoles to 1-Methyl-1H- 1,2,4-triazoles}

\section{Odd R. Gautun and Per H.J. Carlsen*}

Department of Chemistry, Norwegian University of Science and Technology, N-7491 Trondheim, Norway, Tel. +47 735939 68, Fax +47 73594256.

* Author to whom correspondence should be addressed; e-mail: per.carlsen@ @ chembio.ntnu.no

Received: 14 March 2000; in revised form 26 October 2001 / Accepted: 26 October 2001 / Published: 30 November 2001

\begin{abstract}
The rearrangement of 4-methyl-3,5-diaryl-4H-1,2,4-triazoles to the corresponding 1-methyl-3,5-diaryl-1H-1,2,4-triazoles showed regioselectivity comparable to that observed for the alkylation of 3,5-diaryl-1H-1,2,4-triazoles. This lends support to a proposed mechanism for the rearrangement that involves consecutive nucleophilic displacements steps.
\end{abstract}

Keywords: Thermolysis, 1,2,4-triazole, Rearrangement, Regioselective.

\section{Introduction}

Previous studies of the thermal rearrangement reactions of 4-alkyl substituted 4H-1,2,4-triazoles to the corresponding 1-alkyl-1H-1,2,4-triazoles provided evidence supporting the existence of intermolecular nucleophilic displacement reaction pathways, proceeding through the formation of dialkyltriazolium triazolate ion-pair intermediates or neutral molecules in a chain reaction [\$. The nucleophilic nature of these rearrangements therefore suggests that electronic effects may play a role in their outcome. Alkylation of 3,5-disubstituted-1H-1,2,4-triazoles has also been reported to take place exclusively at the ring 1-position [2]. On alkylation of unsymmetrical substituted triazoles Uda et al. [3] 
found that the 1-2 selectivity was affected by the nature of the substituents, and that alkylation takes place preferentially at the nitrogen next to the ring-carbon with the most electron donating group [i selectivity was assumed to be a result of stereoelectronic control. The nucleophilic nature we have proposed for the rearrangement of 4-alkyl-3,5-diphenyl-4H-1,2,4-triazoles to the corresponding 1-alkyl3,5-diphenyl-1H-1,2,4-triazoles should therefore also exhibit sensitivity to electronic effects. In this paper we report a study of the regioselectivity for the rearrangement of a series of unsymmetrically substituted triazoles.

\section{Results and Discussion}

A series of triazoles of the general structures $\mathbf{1}$ and $\mathbf{2}$ were required for this study. They were readily prepared by a modification of a procedure using unsymmetric bis( $\alpha$-alkylaminobenzylidene)-hydrazines, $\mathbf{5}$, which has been described earlier [ 4 ] and is outlined in Scheme 1. Compounds 5 were formed from the corresponding $N, N^{\prime}$-diarylhydrazides, $\mathbf{6}$, which in turn were obtained by reacting aroyl chlorides $\mathbf{7}$ with monohydrazide 8 . In the synthesis of compound 2 a $40 \%$ aqueous methylamine solution was used. For the synthesis of triazole 1 saturated $\mathrm{NH}_{3}$ in 2-propanol was used, which was found to be superior to a procedure described previously by Stollè et al. [F].

\section{Scheme 1}

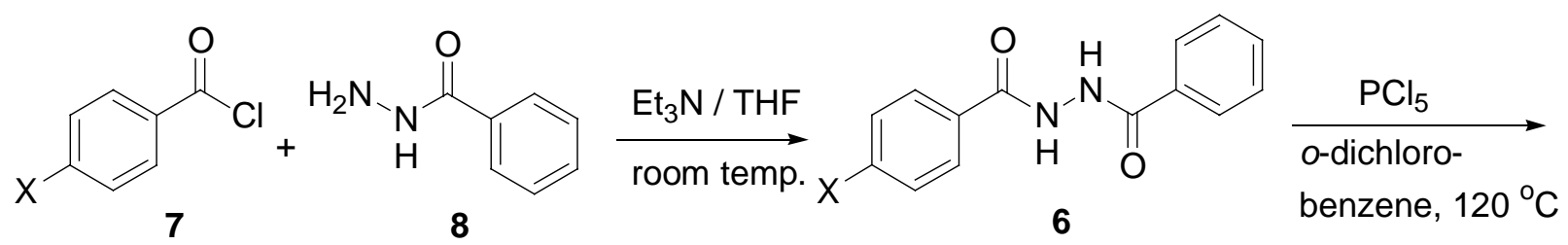<smiles>[X]c1ccc(/C(Cl)=N/N=C(\Cl)c2ccccc2)cc1</smiles>

5

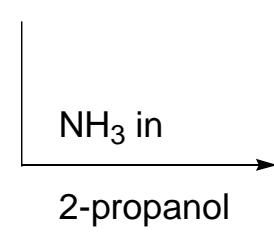<smiles>[X]c1ccc(-c2nnc(-c3ccccc3)n2C)cc1</smiles>

2
$\mathrm{X}$ :

a: $\mathrm{CH}_{3} \mathrm{O}$

b: $\mathrm{CH}_{3}$

c: $\mathrm{Cl}$

$\mathrm{d}: \mathrm{CF}_{3}$

The synthetic results are summarized in Table 1. The yields are those of the pure products obtained after recrystallization or sublimation. 
Table 1. Synthesis of unsymmetrically substituted of 3,5-diaryl-1,2,4-triazoles

\begin{tabular}{|c|c|c|c|}
\hline $\begin{array}{c}\text { Substituent } \\
\text { 4-X }\end{array}$ & $\begin{array}{c}\text { Product 5 } \\
\%\end{array}$ & $\begin{array}{c}\text { Product 1 } \\
\%\end{array}$ & $\begin{array}{c}\text { Product 2 } \\
\%\end{array}$ \\
\hline a: $\mathrm{CH}_{3} \mathrm{O}$ & 49 & 53 & 72 \\
\hline b: $\mathrm{CH}_{3}$ & 28 & $74^{\mathrm{a}}$ & 53 \\
\hline c: $\mathrm{Cl}$ & 57 & 81 & 57 \\
\hline d: $\mathrm{CF}_{3}$ & 75 & 78 & 79 \\
\hline
\end{tabular}

${ }^{\mathrm{a}}$ Yield after sublimation

A series of neat unsymmetrical substituted 4-methyl-3,5-diaryl-4H-1,2,4-triazoles, 2, were next thermolyzed at $330{ }^{\circ} \mathrm{C}$ for $30 \mathrm{~min}$ to investigate the regioselectivity as a function of the electronic conditions induced by the para-substituents in one of the phenyl rings. These results were also compared with those obtained for the selectivity upon alkylation of the corresponding unsymmetrical 3,5-diaryl-1H1,2,4-triazoles, $\mathbf{1}$, with methyl iodide. The general reactions are shown in Scheme 2.

\section{Scheme 2}

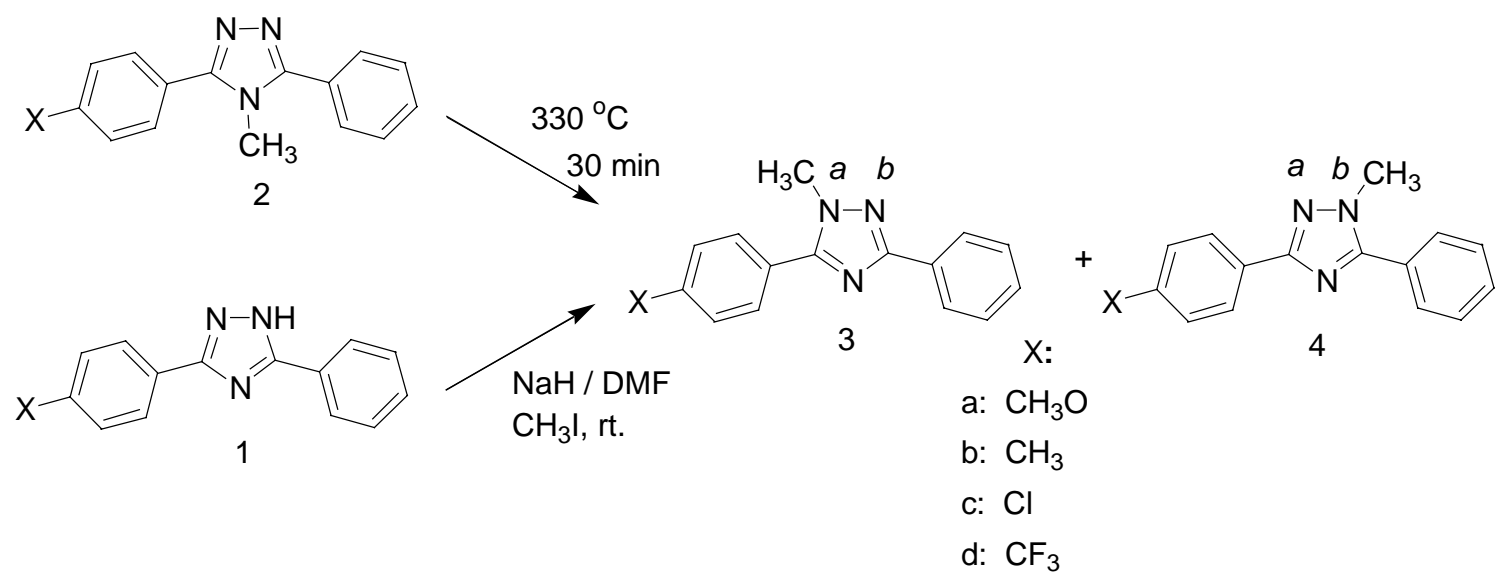

The thermolyses were carried out with samples of the appropriate triazoles in sealed glass tubes under nitrogen at ca. $330{ }^{\circ} \mathrm{C}$ for 30 minutes. The unsymmetrically substituted triazoles rearrange, as expected, to yield mixtures of the two possible regioisomers, i.e., the methyl group migrated to the $a$ - and $b$ - ring positions respectively, as indicated in Scheme 2, thus forming compounds 3 and $\mathbf{4}$. The product distributions are compiled in Table 2 . The results of alkylation of triazole $\mathbf{1}$ with methyl iodide in DMF using sodium hydride as base are also shown. 
Table 2. Distribution of regioisomers 3 and $\mathbf{4}$ on thermolysis of triazoles $\mathbf{2}$ and alkylation of triazoles $\mathbf{1}$ with methyl iodide.

\begin{tabular}{|c|c|c|}
\hline $\begin{array}{c}\text { Substituent } \\
4-\mathbf{X}\end{array}$ & $\begin{array}{c}\text { Thermolysis: } \\
\text { Product distibution } \\
\mathbf{3}: \mathbf{4}\end{array}$ & $\begin{array}{c}\text { Alkylation: } \\
\text { Product distribution } \\
\mathbf{3}: \mathbf{4}\end{array}$ \\
\hline a: $\mathrm{CH}_{3} \mathrm{O}$ & $51: 49$ & $54: 46$ \\
\hline b: $\mathrm{CH}_{3}$ & $52: 48$ & $54: 46$ \\
\hline c: $\mathrm{Cl}$ & $42: 58$ & $40: 60$ \\
\hline d: $\mathrm{CF}_{3}$ & $42: 58$ & $36: 64$ \\
\hline
\end{tabular}

The regioisomer ratios were determined by $400 \mathrm{MHz}$ proton NMR spectroscopy of the crude reaction mixtures by measuring the intensities of characteristic signals. The assignment of the regioisomers was based on comparison of the NMR spectra to those of authentic samples of triazoles 3 [8], which were prepared by independent syntheses. Triazoles 4 were not prepared independently. The experiments were repeated and results were found to be reproducible within 1-2\% of the values reported in the Table.

Authentic samples of the methyl substituted triazoles $\mathbf{3}$ were prepared using a modification of a method developed by Huisgen and coworkers [fo], by reacting 2-methyl-5-phenyl-1H-1,2,3,4-tetrazole [7] with the appropriate 4-substituted benzonitriles, 4-X-Ph-CN, which in general gave better yields than were reported before.

The results reported in Table 2 provide support for the proposed mechanism for the rearrangement reactions. The data from the thermolysis series and the alkylation series, respectively, exhibited the very same trend with respect to regioselectivity. This supports the feasibility of a nucleophilic type mechanism in the rearrangements. The ratios were not identical. However, first of all, the reaction conditions were very different, as were the systems that were reacted. At high temperatures, selectivity will usually diminish. In the two systems, i.e., triazole $\mathbf{1}$ and $\mathbf{2}$, the electronic effects of the substituents may also be transmitted to a different extent to the reaction sites. Thus, it was shown by X-ray crystallography, that due to steric interactions with the methyl group, the phenyl ring in $\mathbf{2}$ are twisted approx. 44 - 48 degrees out of the triazole ring plane, thereby diminishing the overlap of the $\pi$-electron systems [\%]. Triazole 1, on the other hand is nearly planar, with the phenyl ring only 8-9 degrees out of plane [ 9 . Therefore, the trends are similar, but the transmission of electronic effects is diminished for triazoles 2. Electron donating substituents in the aryl group resulted in an increased electron density and therefore increased nucleophilicity at the $a$-position (Scheme 2). As a result of this, products 3 were slightly predominant for aryl groups para-substituted with methoxy- and methyl groups respectively. The opposite effect, as expected, was clearly observed for the electron withdrawing substituents $\left(\mathrm{Cl}-, \mathrm{CF}_{3}-\right)$. 


\section{Conclusions}

The rearrangement of 4-methyl-3,5-diaryl-4H-1,2,4-triazoles to the corresponding 1-methyl-3,5diaryl-1H-1,2,4-triazoles exhibited regioselectivity comparable to that for the alkylation of 3,5-diaryl$1 H$-1,2,4-triazoles, providing further support to the previously proposed mechanism for the rearrangement [19], which would involve consecutive nucleophilic displacements steps (Scheme 3).

\section{Scheme 3}
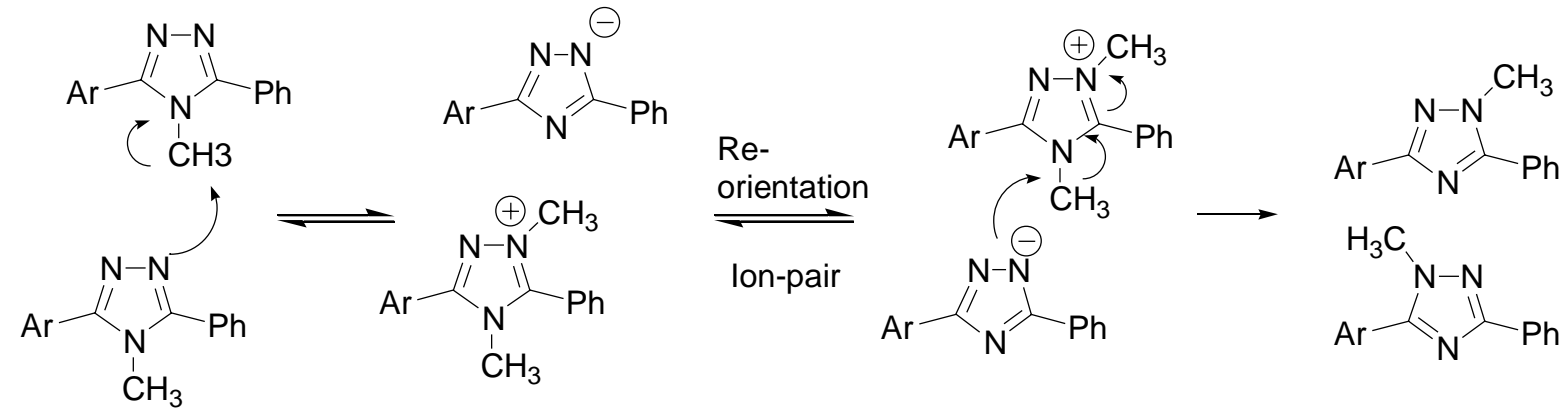

\section{Acknowledgements}

The authors wish to thank The Norwegian Research Council, NFR, for financial support.

\section{Experimental}

\section{General}

${ }^{1} \mathrm{H}$ - and ${ }^{13} \mathrm{C}-\mathrm{NMR}$ spectra were recorded on a JEOL JNM-EX400 FT NMR spectrometer, using $\mathrm{CDCl}_{3}$ as the solvent (unless otherwise indicated) and tetramethylsilane (TMS) as the internal standard. IR and GC-IR spectra were obtained on a Nicolet 20-SXC FT-IR (GC Carlo Erba 5160, 25 m, CP-Sil-5 CB). Mass spectra were recorded on a AEI MS-902 spectrometer at $70 \mathrm{eV}$ (IP). GC measurements were performed on a Varian 3700 capillary gas chromatograph.

\section{Preparation of Substituted N,N'- Dibenzoylhydrazines (6a-d)}

These compounds were prepared by reacting benzhydrazide $\mathbf{8}$ with the appropriate aroyl chlorides 7a-d in dry THF and triethylamine at reflux for $3 \mathrm{hr}$.

2-(4-Methoxybenzoyl)benzhydrazide (6a). Obtained in 74\% yield with m.p. $190-91{ }^{\circ} \mathrm{C}$ (lit. [10] 186-87 $\left.{ }^{\circ} \mathrm{C}\right)$. The IR spectrum was in agreement with literature values [H]. ${ }^{1} \mathrm{H}-\mathrm{NMR}\left(100 \mathrm{MHz}, \mathrm{DMSO}-d_{6}\right): \delta$ 
$3.84(\mathrm{~s}, 3 \mathrm{H}), 7.05(\mathrm{~d}, 2 \mathrm{H}, \mathrm{J}=8.8 \mathrm{~Hz}), 7.50-7.65(\mathrm{~m}, 3 \mathrm{H}), 7.92(\mathrm{~d}, 4 \mathrm{H}, \mathrm{J}=8.3 \mathrm{~Hz}), 10.33$ and 10.41 $(2 \mathrm{H}, \mathrm{NH}) \mathrm{ppm} ; \mathrm{MS}\left[\mathrm{m} / z\right.$ (\% rel. int.)]: $270\left(6, M^{+}\right), 252(6), 135$ (100).

2-(4-Methylbenzoyl)benzhydrazide (6b). Obtained in 76\% yield with m.p. 226-27 ${ }^{\circ} \mathrm{C}$ (lit.[12] 220-21

$\left.{ }^{\circ} \mathrm{C}\right) .{ }^{1} \mathrm{H}-\mathrm{NMR}\left(100 \mathrm{MHz}, \mathrm{DMSO}-d_{6}\right): \delta 2.41(\mathrm{~s}, 3 \mathrm{H}), 7.21-7.28(\mathrm{~m}, 2 \mathrm{H}), 7.35-7.60(\mathrm{~m}, 3 \mathrm{H}), 7.9(\mathrm{~m}$, 4H), 9.42 (2H, NH) ppm. IR (KBr): 3203, 3053, 3003, 1667, 1630, 1536, 1489, 1285, 877, 835, 704 $\mathrm{cm}^{-1}$. MS [m/z (\% rel. int.)]: $254\left(12, M^{+}\right), 119$ (100), 105 (29).

2-(4-Chlorobenzoyl)benzhydrazide (6c). Obtained in $71 \%$ yield with m.p. $230-230.5{ }^{\circ} \mathrm{C}$ (lit.[13] 232.5$\left.233.0{ }^{\circ} \mathrm{C}\right)$. The IR spectrum was in agreement with literature values [10]. ${ }^{1} \mathrm{H}-\mathrm{NMR}(100 \mathrm{MHz}, \mathrm{DMSO}-$ $\left.d_{6}\right)$ : $\delta$ 7.58-7.65 (m, 5H), 7.88-8.00 (m, 4H), 10.50 and $10.58(2 \mathrm{H}, \mathrm{NH}) \mathrm{ppm}$. MS [ $\mathrm{m} / \mathrm{z}(\% \mathrm{rel}$. int.)]: $276(5), 275$ (2), $274\left(11, M^{+}\right), 139$ (43), 105 (100).

2-(4-Trifluoromethylbenzoyl)benzhydrazide (6d). Obtained in $76 \%$ yield with m.p. $205.0-206.5{ }^{\circ} \mathrm{C} .{ }^{1} \mathrm{H}-$ NMR (100 MHz, DMSO- $\left.d_{6}\right): \delta$ 7.40-7.60 (m, 3H), 7.89-8.05 (m, 4H), 8.05-8.20 (m, 2H), $10.65(2 \mathrm{H}$, NH) ppm. IR (KBr): 3251, 3085, 1676, 1631, 1582, 1521, 1486, 1331, 1287, 1173, 1121, 1070, 860, $772 \mathrm{~cm}^{-1}$. MS [m/z (\% rel. int.)]: $308\left(5, M^{+}\right), 173(10), 105$ (100). Calculated for $\mathrm{C}_{15} \mathrm{H}_{11} \mathrm{~F}_{3} \mathrm{~N}_{2} \mathrm{O}_{2}: M^{+}$ 308.0773. Found: 308.0768 .

General Procedure for the Synthesis of Substituted Di( $\alpha$-chlorobenzylidene $)$ hydrazines (5)

$40 \mathrm{mmol}$ of the appropriate dibenzoylhydrazine were added portionwise over $1.5 \mathrm{hr}$ to a stirred mixture of $80 \mathrm{mmol}$ of $\mathrm{PCl}_{5}$ in $30 \mathrm{~mL}$ of 1,2-dichlorobenzene. Evaporation of the solvent gave the desired product, which was recrystallized.

4-Methoxy- $N$-(chlorophenylmethylene)benzencarbohydrazonoyl chloride (5a). Obtained in 49\% yield with m.p. 118-20 ${ }^{\circ} \mathrm{C} .{ }^{1} \mathrm{H}-\mathrm{NMR}(100 \mathrm{MHz}): \delta 3.88$ (s, 3H), 6.96 (d, 2H, J = 8.8 Hz), 7.40-7.54 (m, 3H), 8.03-8.18 (m, 4H) ppm. IR (KBr): 1600, 1590, 1580, 1510, 1486, 1462, 1446, 1420, 1306, 1264, 1220, 1176, 1120, 1029, 1010, 1000, 920, 837, 792, $770 \mathrm{~cm}^{-1}$. MS [m/z (\% rel. int.)]: $306\left(73, M^{+}\right)$. Calculated for $\mathrm{C}_{15} \mathrm{H}_{12} \mathrm{Cl}_{2} \mathrm{~N}_{2} \mathrm{O}: M^{+}$306.0327. Found: 306.0331

4-Methyl-N-(chlorophenylmethylene)benzencarbohydrazonoyl chloride (5b). Obtained in $28 \%$ yield with m.p. 85-86 ${ }^{\circ} \mathrm{C} .{ }^{1} \mathrm{H}-\mathrm{NMR}(100 \mathrm{MHz}): \delta 2.41$ (s, 3H), $7.26(\mathrm{~d}, 2 \mathrm{H}, \mathrm{J}=7.8 \mathrm{~Hz}), 7.40-7.54(\mathrm{~m}, 3 \mathrm{H})$, 7.98-8.17 (m, 4H) ppm. IR (KBr): 1601, 1575, 1563, 1504, 1488, 1445, 1227, 1212, 1177, 915, 822, $791,764 \mathrm{~cm}^{-1}$. MS [m/z (\% rel. int.)]: $290\left(68, M^{+}\right)$. Calculated for $\mathrm{C}_{15} \mathrm{H}_{12} \mathrm{Cl}_{2} \mathrm{~N}_{2}: M^{+} 290.0377$. Found: 290.0379

4-Chloro-N-(chlorophenylmethylene)benzencarbohydrazonoyl chloride (5c). This compound, previously reported by Cronin et al. [18], was obtained in $57 \%$ yield with m.p. $87-88{ }^{\circ} \mathrm{C} .{ }^{1} \mathrm{H}-\mathrm{NMR}$ 
(100 MHz): $\delta$ 7.39-7.54(m, 5H), 8.03-8.20 (m, 4H) ppm. IR (KBr): 1605, 1573, 1490, 1450, 1402, $1228,1174,1096,1019,929,836,766,733 \mathrm{~cm}^{-1}$.

4-(Trifluoromethyl)- $N$-(chlorophenylmethylene)benzencarbohydrazonoyl chloride (5d). Obtained in $75 \%$ yield with m.p. $77-78{ }^{\circ} \mathrm{C} .{ }^{1} \mathrm{H}-\mathrm{NMR}(100 \mathrm{MHz}): \delta 7.37-7.58(\mathrm{~m}, 3 \mathrm{H}), 7.73(\mathrm{~d}, 2 \mathrm{H}, \mathrm{J}=8.3 \mathrm{~Hz})$, 8.08-8.28 (m, 4H) ppm. IR (KBr): 1600, 1576, 1510, 1488, 1447, 1409, 1330, 1218, 1187, 1161, 1113, 1071, 1015, 922, $768 \mathrm{~cm}^{-1}$. MS [m/z (\% rel. int.)]: $344\left(40, M^{+}\right)$. Calculated for $\mathrm{C}_{15} \mathrm{H}_{9} \mathrm{Cl}_{2} \mathrm{~N}_{2} \mathrm{~F}_{3}: M^{+}$ 344.0095. Found: 344.0092.

Synthesis of Unsymmetric 4-Methyl-3,5-diaryl-4H-1,2,4-triazoles (2)

These compounds were prepared from the corresponding di( $\alpha$-chlorobenzylidene $)$ hydrazines, $\mathbf{5}$, as described previously in the literature [14].

3-(4-Methoxyphenyl)-4-methyl-5-phenyl-4H-1,2,4-triazole (2a). The yield of the pure product was 72\% with m.p. $211-13{ }^{\circ} \mathrm{C}$ (recryst. from toluene). ${ }^{1} \mathrm{H}-\mathrm{NMR}$ (400 MHz): $\delta 3.69$ (s, 3H), 3.88 (s, 3H), 7.05 (d, $2 \mathrm{H}, \mathrm{J}=8.8 \mathrm{~Hz}), 7.50-7.55(\mathrm{~m}, 3 \mathrm{H}), 7.67(\mathrm{~d}, 2 \mathrm{H}, \mathrm{J}=8.8 \mathrm{~Hz}), 7.70-7.75(\mathrm{~m}, 2 \mathrm{H}) \mathrm{ppm} .{ }^{13} \mathrm{C}-\mathrm{NMR}(100$ MHz): $\delta 33.2,55.5,114.3,119.6,127.4,128.8,129.4,129.9,130.3,155.8,160.9$ ppm. IR (KBr): 3006, $2965,2937,1615,1540,1483,1439,1296,1255,1182,1040,1029,834,772,741,701 \mathrm{~cm}^{-1}$. MS $[\mathrm{m} / \mathrm{z}$ (\% rel. int.)]: 266(18), $265\left(100, M^{+}\right), 264$ (70), 148 (10), 134 (13), 118 (35). Calculated for $\mathrm{C}_{16} \mathrm{H}_{15} \mathrm{~N}_{3} \mathrm{O}: M^{+}$265.1215. Found: 265.1213. Analysis: Calc. for $\mathrm{C}_{16} \mathrm{H}_{15} \mathrm{~N}_{3} \mathrm{O}: \mathrm{C}, 72.43 ; \mathrm{H}, 5.70 ; \mathrm{N}$, 15.84. Found: C, 72.59; H, 5.91; N, 15.78.

3-(4-Methylphenyl)-4-methyl-5-phenyl-4H-1,2,4-triazole (2b). The yield of the pure product was 53\% with m.p. $236.5-237.5{ }^{\circ} \mathrm{C}$ (recryst. from ethanol). ${ }^{1} \mathrm{H}-\mathrm{NMR}(400 \mathrm{MHz}): \delta 2.44(\mathrm{~s}, 3 \mathrm{H}), 3.70(\mathrm{~s}, 3 \mathrm{H})$, $7.35(\mathrm{~d}, 2 \mathrm{H}, \mathrm{J}=8.5 \mathrm{~Hz}), 7.38-7.56(\mathrm{~m}, 3 \mathrm{H}), 7.62(\mathrm{~d}, 2 \mathrm{H}, \mathrm{J}=8.3 \mathrm{~Hz}), 7.72-7.74(\mathrm{~m}, 2 \mathrm{H}) \mathrm{ppm} .{ }^{13} \mathrm{C}-$ NMR (100 MHz): $\delta 21.4,33.2,124.3,127.3,128.1,128.9,129.6,130.0,135.8,140.2,155.9$ ppm; IR (KBr): 3051, 3037, 3020, 1686, 1619, 1578, 1526, 1485, 1449, 1075, 832, 771, 736, 710, $700 \mathrm{~cm}^{-1}$. MS [m/z (\% rel. int.)]: 250 (17), 249 (100, $M^{+}$), 248 (93), 132 (18), 118 (42). Calculated for $\mathrm{C}_{16} \mathrm{H}_{15} \mathrm{~N}_{3}$ : $M^{+}$249.1266. Found: 249.1268. Analysis: Calc. for $\mathrm{C}_{16} \mathrm{H}_{15} \mathrm{~N}_{3}$ : C, 77.08; H, 6.06; N, 16.85. Found: C, 77.25; H, 6.21; N, 17.01 .

3-(4-Chlorophenyl)-4-methyl-5-phenyl-4H-1,2,4-triazole (2c). The yield of the pure product was 57\% with m.p. $276-77.5{ }^{\circ} \mathrm{C}$ (recryst. from toluene). ${ }^{1} \mathrm{H}-\mathrm{NMR}(400 \mathrm{MHz}): \delta 3.72(\mathrm{~s}, 3 \mathrm{H}), 7.51-7.56(\mathrm{~m}, 5 \mathrm{H})$, 7.68-7.74 (m, 4H) ppm. ${ }^{13} \mathrm{C}-\mathrm{NMR}(100 \mathrm{MHz}): \delta 33.2,125.7,127.1,128.9,129.2,130.1,136.4,154.9$, 156.2 ppm. IR (KBr): 3067, 3051, 3025, 2970, 1605, 1480, 1456, 1437, 1402, 1098, 1074, 1014, 840, 827, $770736,717,701 \mathrm{~cm}^{-1}$. MS [m/z (\% rel. int.)]: 272 (5), 271 (32), 270 (42), 269 (100, $\left.M^{+}\right), 268$ (86), 267 (5), 152 (19), 118 (23). Calculated for $\mathrm{C}_{15} \mathrm{H}_{12} \mathrm{ClN}_{3}$ : 269.0720. Found: 269.0717. Analysis: Calc. for $\mathrm{C}_{15} \mathrm{H}_{12} \mathrm{~N}_{3} \mathrm{Cl}$ : C, 66.79; H, 4.48; N, 15.58; Cl, 13.14. Found: C, 66.65; H, 4.28; N, 15.40. 
3-(4-Trifluoromethylhenyl)-4-methyl-5-phenyl-4H-1,2,4-triazole (2d). The yield of the pure product was $79 \%$ with m.p. $293-94{ }^{\circ} \mathrm{C}$ (recryst. from toluene). ${ }^{1} \mathrm{H}-\mathrm{NMR}(400 \mathrm{MHz}): \delta 3.75(\mathrm{~s}, 3 \mathrm{H}), 7.52-7.58$ (m, 3H), 7.72-7.76 (m, 2H), 7.80, 7.83, 7.89, 7.91 (4H, AA'BB') ppm. IR (KBr): 3074, 3055, 3027, 1481, 1408, 1334, 1319, 1170, 1157, 1116, 1089, 1073, 1061, 1022, 1014, 861, 842, 774, 732, 705 $\mathrm{cm}^{-1}$. MS [m/z (\% rel. int.)]: 304 (16), 303 (94, $M^{+}$), 302 (100), 186 (27), 145 (11), 118 (18), 104 (19). Calculated for $\mathrm{C}_{16} \mathrm{H}_{12} \mathrm{~F}_{3} \mathrm{~N}_{2}$ : 303.0983. Found: 303.0979. Analysis: Calc. for $\mathrm{C}_{16} \mathrm{H}_{12} \mathrm{~N}_{3} \mathrm{~F}_{3}$ : C, 63.36; $\mathrm{H}$, 3.99; N, 13.85; F, 18.79. Found: C, 63.48; H, 4.18; N, 13.67.

General Procedure for the Synthesis of 5-Aryl-3-phenyl-1H-1,2,4-triazoles (1a-d)

The appropriate substituted di( $\alpha$-chlorobenzylidene $)$ hydrazine, 5, $(2 \mathrm{mmol})$ was dissolved in 2-propanol $(100 \mathrm{~mL})$ saturated with $\mathrm{NH}_{3}$, and the resulting mixture was stirred at room temperature overnight and finally refluxed for $30 \mathrm{~h}$. Evaporation of the solvent under reduced pressure gave the crude product, which was further purified by crystallization or sublimation.

3-(4-Methoxyphenyl)-5-phenyl-1H-1,2,4-triazole (1a). Yield $=53 \%$ (after crystallization from toluene). M.p. 169.5-72.0 ${ }^{\circ} \mathrm{C} .{ }^{1} \mathrm{H}-\mathrm{NMR}\left(100 \mathrm{MHz}, \mathrm{DMSO}-d_{6}\right): \delta 3.84$ (s, 3H), 7.10 (d, 2H, J = 8.8 Hz), 7.49$7.53(\mathrm{~m}, 3 \mathrm{H}), 8.00-8.20(\mathrm{~m}, 4 \mathrm{H}) \mathrm{ppm} .{ }^{13} \mathrm{C}-\mathrm{NMR}\left(25 \mathrm{MHz}, \mathrm{DMSO}-d_{6}\right): \delta 55.2,114.2,121.4,125.9$, 127.5, 128.7, 129.3, 129.7, 157.5, 160.3 ppm. IR (KBr): 3500-2500 (broad), 1614, 1508, 1471, 1441, 1408, 1394, 1310, 1304, 1290, 1278, 1260, 1180, 1142, 1034, 982, 836, 749, $722 \mathrm{~cm}^{-1}$. Analysis: Calc. for $\mathrm{C}_{15} \mathrm{H}_{13} \mathrm{~N}_{3} \mathrm{O}$ : C, 71.70; H, 5.21; N, 16.72; O, 6.37. Found: C, 71.88; H, 5.41; N, 16.67 .

3-(4-Methylphenyl)-5-phenyl-1H-1,2,4-triazole (1b). Yield $=74 \%$ after sublimation. M.p. 178-80 ${ }^{\circ} \mathrm{C}$. The spectroscopic properties were all in agreement with those reported in the literature [1ㄱ.

3-(4-Chlorophenyl)-5-phenyl-1H-1,2,4-triazole (1c). Yield $=81 \%$ yield after crystallization from toluene. M.p. $241-42{ }^{\circ} \mathrm{C}$. The spectroscopic properties were all in agreement with those reported in the literature $[10]$.

3-(4-Trifluorophenyl)-5-phenyl-1H-1,2,4-triazole $(\mathbf{1 d})$. Yield $=74 \%$ yield after crystallization from toluene. M.p. $224-26{ }^{\circ} \mathrm{C}$. All the spectroscopic properties were in agreement with those reported in the literature $[17]$.

General Procedure for the Synthesis of 1-Methyl-3-aryl-5-phenyl-1H-1,2,4-triazoles (3a-d).

The method described by Huisgen et al. was applied [6]. Thus, a solution of 2-methyl-5-phenyl$2 \mathrm{H}$-1,2,3,4-tetrazole [7], (2.5 mmol) in the appropriate substituted benzonitrile, $\mathrm{X}-\mathrm{Ph}-\mathrm{CN},(2 \mathrm{~mL})$ was refluxed for 3-5 h under nitrogen. The nitrile was then removed under reduced pressure by Kugelrohr distillation, and the crude product was recrystallized. 
1-Methyl-5-(4-methoxyphenyl)-3-phenyl-1H-1,2,4-triazole (3a). Yield $=39 \%$ of a product of $98 \%$ purity (GC) and with m.p. 82.5-85.5 ${ }^{\circ} \mathrm{C} .{ }^{1} \mathrm{H}-\mathrm{NMR}(400 \mathrm{MHz}): \delta 3.88(\mathrm{~s}, 3 \mathrm{H}), 4.00(\mathrm{~s}, 3 \mathrm{H}), 7.04(\mathrm{~d}, 2 \mathrm{H}$, $\mathrm{J}=8.8 \mathrm{~Hz}), 7.37-7.46(\mathrm{~m}, 3 \mathrm{H}), 7.68(\mathrm{~d}, 2 \mathrm{H}, \mathrm{J}=8.8 \mathrm{~Hz}), 8.14(\mathrm{~d}, 2 \mathrm{H}, \mathrm{J}=6.8 \mathrm{~Hz}) \mathrm{ppm} .{ }^{13} \mathrm{C}-\mathrm{NMR}(100$ $\left.\mathrm{MHz}, \mathrm{CDCl}_{3}\right): \delta 36.9,55.3,114.4,120.3,126.2,128.5,129.0,130.1,131.1,155.4,160.9 \mathrm{ppm}$. IR (KBr): 3040, 3023, 3009, 1611, 1545, 1486, 1473, 1444, 1396, 1355, 1298, 1256, 1186, 1172, 1131, 1033, 1023, 835, 790, 747, 724, $702 \mathrm{~cm}^{-1}$. MS [m/z (\% rel. int.)]: 266 (19), 265 (100, $\left.M^{+}\right), 264$ (9), 132 (60), 131 (19), 105 (18), 104 (25). Calculated for $\mathrm{C}_{16} \mathrm{H}_{15} \mathrm{~N}_{3} \mathrm{O}$ : 265.1215. Found: 265.1213. Analysis: Calc. for $\mathrm{C}_{16} \mathrm{H}_{15} \mathrm{~N}_{3} \mathrm{O}$ : C, 72.43; H, 5.70; N, 15.84. Found: C, 72.28; H, 5.77; N, 15.65.

1-Methyl-5-(4-methylphenyl)-3-phenyl-1H-1,2,4-triazole (3b). Yield $=55 \%$ of a product of $96 \%$ purity (GC) and with m.p. $78-81{ }^{\circ} \mathrm{C} .{ }^{1} \mathrm{H}-\mathrm{NMR}(400 \mathrm{MHz}): \delta 2.44$ (s, 3H), 4.01 (s, 3H), 7.32 (d, 2H, J = 7.3 $\mathrm{Hz})$, 7.37-7.46 (m, 3H), $7.62(\mathrm{~d}, 2 \mathrm{H}, \mathrm{J}=8.3), 8.14(\mathrm{~d}, 2 \mathrm{H}, \mathrm{J}=7.3) \mathrm{ppm} .{ }^{13} \mathrm{C}-\mathrm{NMR}(100 \mathrm{MHz}$, DMSO$\left.d_{6}\right): \delta 21.4,36.9,125.1,126.3,128.5,128.6,129.0,129.4,131.1,140.2,155.7,161.0 \mathrm{ppm}$. IR (KBr): $3072,3024,2946,1610,1482,1472,1447,1353,1138,1070,1014,823,749,735,713 \mathrm{~cm}^{-1}$. MS $[\mathrm{m} / \mathrm{z}$ (\% rel. int.)]: 250(19), 249(100, $M^{+}$), 248(8), 132(62), 131(16), 104(19). Calculated for $\mathrm{C}_{16} \mathrm{H}_{15} \mathrm{~N}_{3}$ : 249.1266. Found: 249.1268. Analysis: Calc. for $\mathrm{C}_{16} \mathrm{H}_{15} \mathrm{~N}_{3}$ : C, 77.08; H, 6.06; N, 16.85. Found: C, 77.20; H, 6.19; N, 16.78 .

1-Methyl-5-(4-chlorophenyl)-3-phenyl-1H-1,2,4-triazole (3c). Yield $=83 \%$ of a product with $>99 \%$ purity (GC) and m.p. 122.0-23.5 ${ }^{\circ} \mathrm{C}$. All spectroscopic properties were in agreement with those reported in the literature [6].

1-Methyl-5-(4-trifluoromethylphenyl)-3-phenyl-1H-1,2,4-triazole $(\mathbf{3 d})$. Yield $=58 \%$ of a product of $99 \%$ purity (GC) and m.p. $131.5-33.5{ }^{\circ} \mathrm{C}$ (lit.[17] 115-17 ${ }^{\circ} \mathrm{C}$ ). ${ }^{1} \mathrm{H}-\mathrm{NMR}(400 \mathrm{MHz}): \delta 4.05(\mathrm{~s}, 3 \mathrm{H}$ ), 7.26-7.45 (m, 3H), 7.79, 7.81, 7.88, $7.90\left(4 \mathrm{H},-\mathrm{AA}^{\prime} \mathrm{BB}\right), 8.14$ (d, 2H, J = 7.6) ppm. ${ }^{13} \mathrm{C}-\mathrm{NMR}(100$ $\left.\mathrm{MHz}, \mathrm{CDCl}_{3}\right): \delta 37.1,123.7,\left(\mathrm{q}, \mathrm{J}_{\mathrm{CF}}=270 \mathrm{~Hz}\right), 125.7,125.9,126.3,128.6,129.1,129.3,130.7,131.5$, 132.6, 154.2, 161.4 ppm. IR (KBr): 3074, 3058, 2955, 2927, 1623, 1472, 1447, 1437, 1331, 1314, 1165, 1122, 1078, 1057, 1023, 1014, 849, 789, 757, 748, 732, $704 \mathrm{~cm}^{-1}$. MS [m/z (\% rel. int.)]: 304 (19), 303 (100, $M^{+}$), 132 (69), 131 (23), 104 (28). Calculated for $\mathrm{C}_{16} \mathrm{H}_{12} \mathrm{~F}_{3} \mathrm{~N}_{3}$ : 303.0983. Found: 303.0981; Analysis: Calc. for $\mathrm{C}_{16} \mathrm{H}_{12} \mathrm{~F}_{3} \mathrm{~N}_{3}$ : C, 63.36; H, 3.99; N, 13.85; F, 18.79. Found: C, 63.61; H, $7.21 ; \mathrm{N}, 13.51$.

Thermolysis of 4-methyl-3-aryl-5-phenyl-4H-1,2,4-triazoles (1).

The triazole (30 mg) was placed under nitrogen in a sealed glass tube and then heated in an oven at 323-35 ${ }^{\circ} \mathrm{C}$ for $30 \mathrm{~min}$. The crude product contained the compounds 3 and 4 . The compositions of the reaction mixtures were determined by $400 \mathrm{MHz}$ NMR spectroscopy by comparison with those of the authentic samples. The regioisomers could not be separated by either GC or TLC. 
Methylation of 3-aryl-5-phenyl-1H-1,2,4-triazoles (1).

An appropriate 3-aryl-5-phenyl-1H-1,2,4-triazole, 1 (30 mmol), was dissolved in dry DMF (1 mL), $0.3 \mathrm{~g} \mathrm{NaH}$ were added and the mixture was stirred under nitrogen for $1 \mathrm{~h}$. Then $\mathrm{CH}_{3} \mathrm{I}(0.30 \mathrm{mmol})$ was added and the reaction mixture stirred for $48 \mathrm{~h}$. Water was added and the mixture extracted with $\mathrm{CH}_{2} \mathrm{Cl}_{2}$, yielding the crude product which was analyzed by NMR as described above.

\section{References}

1 Carlsen, P.H.J.; Gautun, O.R. Acta Chem. Scand. 1990, 44, 485

2 (a) Lee, L.A.; Evans, R.; Wheeler, J.W. J. Org. Chem. 1972, 37, 343; (b) Atkinson, M.R.; Polya, J.B. J. Chem. Soc. 1954, 141

3 Uda, M.; Hisazumi, Y.; Sato, K.; Kubota, S. Chem. Pharm. Bull. 1975, 24, 3103

4 Gautun, O.R.; Carlsen, P.H.J. Acta Chem. Scand. 1991, 45, 609

5 Stollè, R.; Thimä, K. J. Prakt. Chem. 1906, 73, 288.

6 (a) Fliege, W.; Grashey, R.; Huisgen, R. Chem. Ber. 1984, 117, 1194; (b) Huisgen, R.; Seidel, M.; Sauer, J.; McFarland, J.W.; Wallbillich, G. J. Org. Chem. 1959, 24, 892.

7 Henry, R.A. J. Am. Chem. Soc. 1951, 73, 4470.

8 Carlsen, P.H.J.; Jørgensen, K.B.; Gautun, O.R.; Jagner, S.; Håkansson, M. Acta Chem. Scand. 1994, 49, 676.

9 Carlsen, P.H.J.; Gautun, O.R.; Samuelsen, E.J.; Mårdalen, J.; Helgesson, G.; Jagner, S. Physica Scripta 1991, 44, 214.

10 Grekov, A.P.; Kulakova, L.N.; Shvaika, O.P. J. Gen. Chem., USSR. 1966, 29, 3020

11 Zadorozhnyi, B.A.; Ishcenko, I.K.; Mnatsakanova, T.R.; Shvaika, O.P. J. Org. Chem., USSR. 1966, 2, 431

12 Gilbert, E.C. J. Am. Chem. Soc. 1927, 49, 286.

13 Beck, H.; Kroner, J. Chem. Ber. 1966, 99, 2039.

14 Gautun, O.R.; Carlsen, P.H.J. Acta Chem. Scand. 1991, 45, 609.

15 Whitfield, L.A.; Papadopoulos, E.P. J. Heterocycl. Chem. 1981, 18, 1197.

16 Pèrez, M.A.; Dorado, C.A.; Soto, J.L. Synthesis 1983, 483.

17 Lin, Y.-I; Hlavka, J.J.; Bitha, P.; Lang, S.A. J. Heterocycl. Chem. 1983, 20, 1693.

18 Cronin, J.; Hegarty, A.F.; Cashell, P.A.; Scott, F.L. J. Chem. Soc., Perkin Trans II. 1973, 1708.

19 Gautun, O.R.; Carlsen, P.H.J. Eur. J. Org. Chem. 2000, 3749.

Sample Availability: Available from the authors.

(C) 2001 by MDPI (http://www.mdpi.org). Reproduction is permitted for noncommercial purposes. 